\title{
The Next Generation Science Standards are Coming to Wisconsin
}

\author{
Shelley Lee \\ Wisconsin Department of Public Instruction
}

\begin{abstract}
The Wisconsin Space Grant Consortium provided the state science leadership team with a grant that funded a meeting of the state appointed science leadership team. Occurring at a critical time, the team was able to respond to a draft the of the Next Generation Science Standards on behalf of science teachers around the state. The team then was able to develop a comprehensive plan of implementation for the standards.
\end{abstract}

Through a collaborative state-led process, new K-12 science standards have been developed that are rich in content and practice and arranged in a coherent manner across disciplines and grades to provide all students an internationally benchmarked science education. Developed by Achieve, Inc. Next Generation Science Standards (NGSS) are based on the Framework for K12 Science Education published by the National Research Council. These standards were derived from contemporary science education research and pedagogical practices. They represent the essential science content that all students should know and understand in order to be successful in this contemporary and global society.

State Superintendent Tony Evers appointed a science leadership team whose make-up consisted of K-12 educators, higher education faculty, technical college faculty, and community members from around the state. He charged this team with the task of responding to all NGSS drafts on behalf of the state. They accomplished this by gathering feedback from every CESA through listening and preview sessions. The team was also charged with developing state level implementation plan, which is now being implemented.

The Wisconsin Space Grant Consortium funded a January 2013 leadership team meeting. It was held in Green Bay and Dr. Aileen Yingst, the space grant director, was the keynote. The funds for the meeting came at a strategic time because the second draft of the NGSS was just released. The leadership team was able to develop a cogent and appropriate response to the draft that reflected what was important for students to know and understand in Wisconsin science education. The leadership team also developed the state's NGSS implementation plan during this meeting that was a reflection on NASA's STEM initiatives.

As a result of this meeting, the following activities took place:

- The leadership team had a clear picture of the NGSS.

- The state superintendent's cabinet was briefed on the NGSS.

- Over 600 educators attended a preview session conducted by the leadership team that were held in various locations around the state. 
The Wisconsin Department of Public Instruction is grateful to the Wisconsin Space Grant Consortium for funding one of the science leadership team meetings. Without space grant's support the Next Generation Science Standards would not be a reality in Wisconsin. To date, over 1,500 teachers of science and administrators have been exposed to the NGSS; this is the result of that January meeting.

References:

CESA conversations as recorded by Kevin Anderson, conference call facilitator. April 2013.

Garet, M. Proter, A., Desimone, L. et al., 2001. What makes professional development effective? Results from a National Sample of Teachers. American Educational Research Journal 38 no. 4: 915-945.

Moon, J., Michaels, S., \& Reiser, B.J. (2013, November 30, 2012). Science standards require a teacher-learning rethink, Commentary. Education Week. Retrieved from http://www.edweek.org/ew/articles/2012/11/30/13moon.h32.html

National Research Council. (2007). Taking science to school: Learning and teaching science in grades K-8. Washington, DC: National Academies Press.

National Research Council. (2012). A framework for K-12 science education: Practices, crosscutting concepts, and core ideas. Washington, DC: National Academies Press.

NGSS Lead States. (2013). Next Generation Science Standards: For states, by states. Washington, DC: The National Academies Press.

Wisconsin Department of Public Instruction. 2012. Wisconsin science leadership team needs assessment results, unpublished. 